\title{
RELATIVIZAÇÃO DA PRESUNÇÃO DE INOCÊNCIA SOBRE O PRISMA DA INTEGRIDADE E COERÊNCIA DE RONALD DWORKIN
}

\author{
Hamilton da Cunha Iribure Júnior ${ }^{1}$ \\ Moisés dos Santos Rosa ${ }^{2}$
}

Resumo: O presente trabalho objetiva estabelecer uma análise crítica sobre a decisão do HC 126.292 pelo Supremo Tribunal Federal que relativizou o princípio constitucional da presunção de inocência e rompeu com entendimento que se encontrava já sedimentado desde o ano de 2009. Partindo do posicionamento dos Habeas Corpus de $n^{0}$ s 84.078/SP e 126.292/SP, pretende-se analisar se há algum ponto de integração, coerência e uniformidade entre essas duas decisões sob o prisma interpretativo proposto por Ronald Dworkin, assim como se busca analisar de forma crítica se essa decisão foi meramente política ou casuística.

Palavras-chave: presunção, relativização, integridade, coerência, inocência.

\section{RELATIZATION OF PRESUMPTION OF INNOCENCE ON THE PRISM OF INTEGRITY AND COHERENCE OF RONALD DWORKIN}

\begin{abstract}
The present work aims to establish a critical analysis of the decision of HC 126.292 by the Federal Supreme Court that relativized the constitutional principle of the presumption of innocence and broke with understanding that had already been settled since the year 2009 . Starting from the Habeas corpus position of ns 84.078 / SP and 126.292 / SP, it is sought to analyze if there is any point of integration, coherence and uniformity between these two decisions under the interpretive prism proposed by Ronald Dworkin, as well as to analyze critically whether this decision was purely political or casuistry.
\end{abstract}

Keywords: presumption, relativization, integrity, coherence, innocence.

\section{INTRODUÇÃO}

\footnotetext{
${ }^{1}$ Doutor e Mestre em Direito pela Pontifícia Universidade Católica, PUC - SP, (Brasil). Docente da Graduação e do Programa de Mestrado da Faculdade de Direito do Sul de Minas, FDSM -MG, (Brasil). E-mail: hamilton.adv@terra.com.br

2 Mestrando em Direito pela Faculdade de Direito do Sul de Minas, FDSM - MG, (Brasil). E-mail: moisesrosa@adv.oabsp.org.br
} 
No ano de 2009, o Supremo Tribunal Federal revisou sua jurisprudência e decidiu quando do julgamento do Habeas Corpus n 84.078-7/MG pela impossibilidade da execução provisória da pena, uma vez, que por força da norma contida na Constituição Federal (art. 5, LVII, da CRFB/88), a presunção de inocência vigoraria até o momento anterior ao trânsito em julgado da sentença penal condenatória, não se admitindo, assim, a prisão do acusado, salvo se presentes os pressupostos de prisão cautelar.

Recentemente, porém, a mesma Suprema Corte, no julgamento do Habeas Corpus $n^{\circ}$ 126.292/SP, rompeu com esse entendimento que já estava sedimentado desde o ano de 2009 e decidiu que a execução provisória de acórdão prolatado em recurso de apelação, ainda que pendente recurso especial ou extraordinário, não afrontaria o princípio da presunção de inocência previsto constitucionalmente.

O presente artigo analisa essas duas decisões sob o prisma interpretativo da coerência e integridade do sistema proposto por Ronald Dworkin tendo como parâmetro o romance em cadeia, ilustrado em sua obra. Nesse sentido, para o autor:

$\mathrm{O}$ ato de decidir não pode ser visto como a possibilidade de os julgadores escreverem uma série de contos independentes, sem qualquer correlação entre si, mas, ao contrário, antes, devem ter o compromisso com um romance único, cujo enredo se mostre integrado (DWORKIN, 2007, p. 275).

Partindo dos pressupostos utilizados para o julgamento dessas duas decisões, pretendese analisar através de alguns dos institutos inseridos em nosso ordenamento jurídico autorizam de alguma forma a relativização do princípio da presunção de inocência. No primeiro capitulo o artigo traz de forma sumária a construção histórica e jurisprudencial do Supremo Tribunal Federal sobre o tema.

Faz-se ainda uma analise dessa oscilação jurisprudencial sob o prisma teórico de Ronald Dworkin, verificando se há algum ponto de integração e coerência que permita considerar essas decisões como apenas mais um capítulo decorrente de outras decisões tomadas anteriormente ou se houve, ao contrário, uma absoluta ruptura de interpretação por parte do Supremo Tribunal Federal. 


\section{RELATIVIZAÇÃO DA PRESUNÇÃO DE INOCÊNCIA SOBRE O PRISMA DA INTEGRIDADE E COERÊNCIA DE RONALD DWORKIN}

São descritos também a previsão normativa infraconstitucional que tratam da questão da execução provisória da sentença, onde permite verificar que tanto a fundamentação da ausência de efeito suspensivo dos recursos extremos, quanto a previsão ordinária da Lei de execução Penal são obstáculos que impediriam a mudança dessa ruptura do princípio constitucional da presunção de inocência.

Para serem alcançados tais resultados, a partir da metodologia analítica, vale-se dos aportes teóricos da hermenêutica política de Ronald Dworkin, em especial a ideia do direito como integridade, que exige por parte do Poder Judiciário uma análise voltada à avaliação do passado, do presente e do futuro, na qual cada juiz passa a ser parte de um complexo empreendimento.

Desse modo, espera-se que o presente artigo possa colaborar, ainda que de modo modesto, para análise e reflexão sobre os limites interpretativos que possam existir na extração das normas contidas na Constituição da República pela Suprema Corte.

\section{ANÁLISE DA CONSTRUÇÃO JURISPRUDENCIAL NO STF.}

Historicamente, a presunção de inocência nos moldes embrionários de um Estado Democrático de Direito surgiu no iluminismo, traço distintivo das preocupações penais e das mazelas prisionais com que se deparavam os condenados da época, considerados inclusive hereges diante daquele modelo estatal.

Desde a época de Becaria, em sua clássica obra (BECARIA, 2010) publicada em 1764, já se pontuava a preocupação no processo de expiação das penas sob o enfoque da presunção de inocência. Segundo o Marquês: "um homem não pode ser considerado culpado antes da sentença do juiz; e a sociedade só lhe pode retirar a proteção pública, depois que seja decidido ter ele violado as condições com as quais tal proteção lhe foi concedida” (BECARIA, 2010, p. 35).

Nesse mesmo sentido, Cesare Becaria qualificou de tirânica a prática de se condenar um acusado sem se ter cumprido uma “carga” de demonstrar com certeza sua culpabilidade, sustentando que "ainda nos delitos de difícil comprovação, que são recebidos pelos princípios admitem hipóteses tirânicas, as quase evidências, as semi-provas (como se um homem pudesse ser semi-inocente ou semi-culpado, e sendo, ser semi-punível, ou semi-absolvido) (Ibidem, 
p.50)”. Assim, segundo o citado autor, não se pode imputar a culpabilidade a alguém antes da sentença judicial.

O reconhecimento de forma expressa da presunção de inocência se deu na Declaração de Direitos do Homem e do Cidadão de 1789, que registrava que todo homem deveria ser presumidamente inocente até que fosse declarado culpado e, se julgado indispensável prendêlo, todo o rigor desnecessário para detê-lo deveria ser severamente reprimido pela lei (art. $9^{\circ}$ ). A partir disso, outros diplomas legislativos, inclusive na ordem internacional, incorporaram a presunção de inocência, como a Declaração Universal de Direitos Humanos, de 1948, o Pacto Internacional sobre Direitos Civis e Políticos, de 1966, e a Convenção Americana sobre Direitos Humanos (Pacto de São José da Costa Rica), de 1969.

Por fim, em 1988, foi assegurada na Constituição da República de 1988, no seu art. 5. ${ }^{\circ}$, LVII, com status de direito fundamental, o princípio da presunção de inocência, nos ao afirmar que ninguém será considerado culpado antes do trânsito em julgado da sentença penal condenatória.

No entanto, apesar de a Constituição afirmar expressamente a necessidade de se aguardar o trânsito em julgado da decisão judicial para que a referida garantia deixe de ser presumida, sempre se questionou a respeito da possibilidade de execução provisória da pena a partir da decisão proferida por um Tribunal em segunda instância, na medida em que os recursos extremos - extraordinário e especial - não possuem efeito suspensivo (conforme o já revogado $\S 2^{\circ}$, do art. 27, da Lei 8.038/90), além de não haver a análise de provas. É bem verdade que mesmo com a previsão literal da presunção de inocência, também sob a égide da Constituição da República de 1988, o Supremo Tribunal Federal, já havia de alguma forma, se manifestado favorável à execução provisória antes do trânsito em julgado.

Nesse diapasão, no julgamento do Habeas Corpus 68.726/DF, ocorrido em 28.06.91, da relatoria do ministro Néri da Silveira, firmou-se inicialmente um entendimento no sentido de que a execução provisória da pena não conflitaria com a norma do art. 5º, inciso LVII, da Carta Constitucional, a ordem para que se expedisse mandado de prisão do réu, cuja condenação à pena privativa de liberdade se confirmasse, unanimemente, no julgamento de sua apelação contra a sentença desfavorável, ainda que pendente o julgamento de recurso especial ou extraordinário nas instâncias superiores, uma vez que o artigo 618 do CPP, bem como o §2º , do 


\section{RELATIVIZAÇÃO DA PRESUNÇÃO DE INOCÊNCIA SOBRE O PRISMA DA INTEGRIDADE E COERÊNCIA DE RONALD DWORKIN}

art. 27, da Lei 8.038/90, que afirmavam a ausência de efeito suspensivo nos recursos extraordinário e especial.

Da mesma forma, no julgamento do Habeas Corpus n. ${ }^{0}$ 74.983/DF, de relatoria do ministro Carlos Velloso, ocorrido em 30.06.97, o STF decidiu que, por não terem efeito suspensivo, os recursos especial e extraordinário não impediriam o cumprimento de mandado de prisão. Nessa mesma trilha, no âmbito das turmas do STF, até o ano de 2009, prevalecia o entendimento de que era possível a execução provisória da condenação, depois de confirmada a sentença condenatória pelo órgão Judiciário de segundo grau, visto que os recursos eventualmente enviados, especial e extraordinário, não eram e se mantêm não sendo dotados de efeito suspensivo, nos termos do art. 27 , $\S 2^{\circ}$, da Lei n. ${ }^{\circ} 8.038 / 90$.

Aliás, com base nesse entendimento, até então predominante, foi editada a Súmula n. ${ }^{\circ}$ 716, do STF, a qual admite a progressão de regime de cumprimento da pena ou a aplicação imediata de regime menos severo nela determinada, antes do trânsito em julgado da sentença condenatória. No entanto, a fundamentação da Suprema Corte estava amparada no sentido de que a execução provisória dos julgados poderia ser realizada porque os recursos aos Tribunais Superiores não eram dotados de efeito suspensivos, todavia, a finalidade dessa exceção era completamente diversa.

Disso, verifica-se que o entendimento pela conformidade da execução provisória da pena com o princípio constitucional da presunção de inocência foi no sentido de que, como os recursos extremos - extraordinário e especial - não possuem efeito suspensivo, far-se-ia possível o cumprimento antecipado de pena, uma vez que os dispositivos processuais (em especial, o §2º art. 27, da Lei 8.038/90 e o art. 637 do CPP) autorizariam tal conclusão.

Esse entendimento perdurou até fevereiro de 2009, quando no julgamento do Habeas Corpus n. ${ }^{\circ}$ 84.078/ $\mathrm{MG}^{3}$, de relatoria do ministro Eros Grau, quando a Suprema Corte reformulou o seu entendimento sob o argumento de que o fato de existir recursos sem efeitos suspensivos (especial e extraordinário) não autorizaria cumprimento de prisão antes do trânsito em julgado, já que a presunção de inocência acompanha o agente em todas as instâncias processuais, de modo que a restrição a tal garantia representaria, ainda, afronta à ampla defesa, além de fazer a distinção entre condenados definitivamente e aqueles não o foram por decisão transitada em julgado.

\footnotetext{
${ }^{3}$ Cf. BRASIL. Supremo Tribunal Federal. Habeas Corpus 84.078 MG.
} 
Desse modo, por maioria (07 votos a 04) e nos termos do voto do relator, assentou-se que a execução provisória da pena, sem que se operasse o trânsito em julgado da sentença penal condenatória, implicava em afronta ao princípio da presunção de inocência, plasmado no art. 50, inciso LVII, da Carta da República. Estava, portanto, sedimentada a jurisprudência da Suprema Corte com a proibição da execução provisória sem o trânsito em julgado da sentença condenatória, alinhando-se ao que preconizava tanto os institutos internacionais ${ }^{4}$ quanto a norma interna prevista na Constituição da República.

Todavia, o Supremo Tribunal Federal, no julgamento do Habeas Corpus n. ${ }^{\circ}$ 126.292/SP ocorrido em 17.02.2016, da relatoria do ministro Teori Zavascki, alterou radicalmente a sua jurisprudência acerca do princípio da presunção de inocência, rompendo um sistema de garantias que ocorria na Constituição da República.

\section{LEITURA DA OSCILAÇÃO JURISPRUDENCIAL DO STF SOB O PRISMA DA COERÊNCIA E DA INTEGRIDADE DE RONALD DWORKIN}

A ideia do Direito como Integridade encontra suporte na figura do chain novel de Ronald Dworkin. Ela exige que a decisão jurídica justifique os princípios utilizados nas decisões passadas como uma história digna de ser contada (SIMIONI, 2014, p. 382) e justificada por princípios. Além disso, a coerência exigida pela integridade traz o desafio à decisão judicial de interpretar o caso concreto de modo a reconstruir os motivos passados no “sentido de encontrar a melhor justificação dessa prática (Ibidem, p. 384)”.

Nesse contexto, cada juiz assume a posição de um romancista na corrente, devendo ler tudo o que já foi escrito por outros juízes, no passado, para que se possa chegar a uma opinião sobre a obra coletiva desses mesmos juízes, uma vez que:

Ao decidir o novo caso, cada juiz deve considerar-se como parceiro de um complexo empreendimento em cadeia, do qual essas inúmeras decisões, estruturas, convenções e práticas são a história; é seu trabalho continuar essa história no futuro por meio do que ele faz

\footnotetext{
${ }^{4}$ Declaração Universal de Direitos Humanos, de 1948, Pacto Internacional sobre Direitos Civis e Políticos, de 1966, e a Convenção Americana sobre Direitos Humanos (Pacto de São José da Costa Rica), de 1969.
} 


\section{RELATIVIZAÇÃO DA PRESUNÇÃO DE INOCÊNCIA SOBRE O PRISMA DA INTEGRIDADE E COERÊNCIA DE RONALD DWORKIN}

agora. Ele deve interpretar o que aconteceu antes porque tem responsabilidade de levar adiante a incumbência que tem em mãos e não partir em uma nova direção (DWORKIN, 2005, p.238)

Nesse sentido, conforme Lenio Streck (STRECK, 2014, p. 529) a integridade e a coerência englobam métodos de interpretação construídos ao longo dos anos pela teoria constitucional, como a unidade da Constituição, concordância prática, efeito integrador e proporcionalidade. A integridade exige que os juízes construam seus argumentos de forma integrada ao conjunto do direito. O respeito à tradição é antirrelativista e supera subjetivismos.

Analisando a decisão da relativização da presunção de inocência sob o prisma interpretativo de Ronald Dworkin, o ato de decidir não pode ser realizado sem levar em conta outras decisões a respeito ou sem se considerar a coerência e integridade do sistema a que estão inseridas, eis que se deve haver uma correlação entre uma decisão presente que fatalmente será decorrente de outra anteriormente decidida. Isso significa dizer que as decisões políticas ou judiciais futuras devem respeitar o sistema a que estão inseridas de forma íntegra e coerente. A integridade, ainda, exige que o direito seja visto como totalidade.

Ao proceder à reconstrução histórica-institucional dos princípios que justificaram a mudança de entendimento, faz-se pertinente debruçar a respeito de argumentos de princípio e de política trabalhada por Dworkin que, conforme Francisco José Borges Motta:

Dworkin ensina que argumentos de princípio são argumentos em favor de um direito, e que argumentos de política são argumentos em favor de algum objetivo de cariz coletivo, geralmente relacionado ao bem comum (noutras palavras: os princípios são proposições que prescrevem direito; as políticas são proposições que prescrevem objetivos). Dworkin defende a tese - e com ele concordamos - de que as decisões judiciais devem ser geradas por princípios, e não por políticas. Isso decorre da promessa de um Estado Democrático (que tenha igual interesse por seus cidadãos) de que seus conflitos mais profundos entre indivíduos e sociedade irão, algum dia, em algum lugar, tornar-se finalmente questões de justiça. Em todo caso, os argumentos de princípios somente justificarão uma decisão quando for possível mostrar que o princípio citado é compatível com decisões anteriores que não foram rejeitadas, e com decisões que a instituição está preparada para tomar em circunstâncias hipotéticas (universalização da argumentação) (MOTTA, 2010, p. 217-218)

Nesse aspecto, percebe-se que os argumentos de princípio dizem respeito a um direito que o cidadão tem ao passo que os de 
política, vão dizer geralmente acerca de um objetivo ou de algum resultado que tal escolha possa ocasionar. No caso da presunção de inocência, importante a análise de trecho do voto do ministro Barroso:

Em suas palavras:

Com o esgotamento das instâncias ordinárias, a execução da pena passa a constituir exigência de ordem pública (art. 312, CPP), necessária para assegurar a credibilidade do Poder Judiciário e do sistema penal. Nessa hipótese, dispensa-se motivação específica do magistrado da necessidade de "garantia da ordem publica" e do não cabimento das medidas cautelares alternativas (grifos acrescidos).

Além deste voto não estar baseado em argumentos de princípio, também houve menção à credibilidade do Judiciário e do sistema penal (argumentos de política), além de não estar em consonância com decisões anteriores baseadas em princípios. Nesse aspecto, como sustenta Dworkin “um precedente é um relato de uma decisão política anterior; o próprio fato dessa decisão, enquanto fragmento da história política, oferece alguma razão para se decidir outros casos de maneira similar no futuro”. Além disso, válido mencionar que a força gravitacional de um precedente, conforme Dworkin, só deve levar em consideração os argumentos de princípio que justificam esse precedente (DWORKIN, 2010, p. 176).

Registre-se ainda que, de 2009 a 2016, o Supremo Tribunal Federal se manteve fiel ao entendimento esposado no Habeas Corpus 84.078-7/MG, no sentido de que a prisão de uma pessoa deve estar fundamentada nos requisitos que autorizam a segregação cautelar, haja vista que a execução provisória da pena viola o princípio constitucional da presunção de inocência. No entanto, em fevereiro de 2016, ao julgar o Habeas Corpus $\mathrm{n}^{\circ}$ 126.292/SP, a Corte Suprema rompeu com entendimento outrora consagrado no sentido de que, ante a ausência de efeito suspensivo nos recursos extremos e do esgotamento das instâncias ordinárias - o que impediria a análise de provas - far-se-ia possível a execução provisória de um acórdão condenatório, ainda que ausentes os requisitos da segregação cautelar.

Ronald Dworkin (2007, p.221), analisando o direito como interpretação, embora reconheça as peculiaridades dessa área do conhecimento, afirma que a intepretação jurídica não pode ser vista como se fosse uma atividade "sui generis”, devendo ser estudada como uma atividade geral de interpretação. Dito de outro modo, as relações conflituosas entre garantias e 


\section{RELATIVIZAÇÃO DA PRESUNÇÃO DE INOCÊNCIA SOBRE O PRISMA DA INTEGRIDADE E COERÊNCIA DE RONALD DWORKIN}

eficácia no processo penal reclamam uma hermenêutica que, sem a pretensão de conter a última palavra, busque o necessário “estranhamento” à luz das ideias de romance em cadeia, sobretudo porque meras razões utilitaristas ou imediatistas não se sobrepõem a argumentos de princípio, pautados na coerência e na integridade do Direito.

Partindo dessa ideia, o autor sugere um exercício interpretativo do direito fundamentado na literatura, propondo um gênero artificial por ele denominado "romance em cadeia”, no qual um grupo de romancistas escreve um único romance em série, devendo cada romancista dessa cadeia, interpretar os capítulos precedentes do romance para que se possa escrever um novo capítulo, que vai sendo acrescentado ao anterior.

Os romancistas posteriores da cadeia hão de adotar esse mesmo procedimento, levando a sério suas responsabilidades de dar continuidade, para que criem em conjunto um único romance, da melhor qualidade possível (DWORKIN, 2007, p.276). Dworkin (2005, p.238) observa que a similaridade da atuação judicial no decidir casos difíceis com o estranho exercício literário por ele proposto, com diversos autores, mostra-se mais nítida no sistema da “common law”, em que inexiste lei ocupando posição central capaz de orientar o percurso decisório, fazendo com que os fundamentos da decisão judicial sejam buscados em regras ou princípios, subordinados nas decisões pretéritas de outros juízes, sobre questões semelhantes.

Dworkin não pretendia considerar como inaplicável a sua ideia interpretativa ao sistema da "civil law", como é o caso brasileiro, possuidor, ainda de uma Constituição classificada como analítica. Ao contrário, no sistema jurídico brasileiro, o desenrolar do romance em cadeia é uma tarefa mais complexa, pelo simples fato de existir um texto legal a definir o roteiro do romance.

Analisado sob o prisma da “civil law”, o romancista primeiro é sempre o constituinte, que abre as páginas de um novo romance, escrevendo seu capítulo inaugural, no que será seguido pelos intérpretes da Constituição, dentre os quais se encontra, por óbvio, a função do Poder Judiciário. Dworkin (2005, p. 251) observa ainda que a tarefa de interpretar não se confunde com a tarefa de inventar. O autor esclarece que não pretende, de modo algum, com essa afirmação, fazer crer que todo o significado de um texto encontra-se "simplesmente ali”.

Contudo, enfatiza que o que distingue a interpretação da criação é que naquela o texto interpretado, exerce alguma restrição sobre o resultado da interpretação, o que inexiste na criação (2005, p. 253). Não existe, desse modo, a possibilidade de que os romancistas leiam a 
intepretação correta de maneira mecânica, como se todo o sentido do texto se encontrasse nele próprio.

Todavia, é preciso que se tenha como ponto de partida interpretativo o fato de que, à exceção do primeiro romancista (que no caso brasileiro é o constituinte originário), todos os demais devem ter consciência de que interpretar corretamente o texto não se confunde com iniciar um novo romance deles próprios. (DWORKIN, 2005, p.236-237).

Nas palavras de Dworkin, “o dever de um juiz é interpretar a história jurídica que encontra não inventar uma história melhor” (2005, p.240). A ideia do "romance em cadeia” associada à coerência narrativa brota como elemento fundamental da Teoria Hermenêutica da Responsabilidade, inserindo o intérprete na cadeia da interpretação em prol do reconhecimento da história institucional do Direito, a partir das dimensões do ajuste e da finalidade, além do limite interpretativo decorrente da concepção de integridade do sistema o que implica em rejeitar apreciações pautadas no subjetivismo decisório, à luz de um dever de responsabilidade política .

Cada juiz é como um "romancista na corrente. (...) Ao decidir o novo caso, cada juiz deve considerar-se como parceiro de um complexo empreendimento em cadeia, do qual essas inúmeras decisões, estruturas, convenções e práticas são a história; é seu trabalho continuar essa história no futuro por meio do que ele faz agora. "Ele deve interpretar o que aconteceu antes porque tem a responsabilidade de levar adiante a incumbência que tem em mãos e não partir em alguma nova direção” (DWORKIN, 2001, p. 236).

Nesse contexto, qualquer dos sistemas utilizados (common law ou civil law) em que se analise a decisão do Supremo Tribunal Federal no habeas corpus $n^{\circ} 126.292$ verifica-se que houve uma ruptura total do entendimento adotado anteriormente no habeas $\mathrm{n}^{\circ}$ 84.078-7/MG, julgado em 5 de fevereiro de 2009, quando ficou assentado que somente para a conveniência dos juízes e não do processo penal, se poderia admitir a antecipação da execução penal, mas mais do que isso, verificou-se a falta de comprometimento do Poder Judiciário ao afrontar o texto literal da Constituição Federal.

Partindo da premissa de que a Constituição assegura que ninguém será considerado culpado até o trânsito em julgado da sentença penal condenatória, bem como que a execução de uma pena somente pode ser legitimamente imposta a quem é tido como culpado, não há 


\section{RELATIVIZAÇÃO DA PRESUNÇÃO DE INOCÊNCIA SOBRE O PRISMA DA INTEGRIDADE E COERÊNCIA DE RONALD DWORKIN}

como negar a ruptura da nova intepretação exarada pelo Supremo Tribunal Federal com o romance pelo Constituinte no artigo 5º inciso LVII, da Constituição da República.

O texto interpretado deve impor limites ao resultado da interpretação, o que evidentemente, com o devido respeito às opiniões contrárias, inexistiu quando do julgamento do habeas corpus $n^{0}$ 126292/SP pelo Supremo Tribunal Federal, por melhores que sejam os argumentos a favor desta decisão, até porque é preciso que no processo hermenêutico o texto seja levado a sério (STRECK, 2014, p. 437).

Observa-se ainda que nas duas decisões analisadas pela Suprema Corte, enquanto no Habeas corpus $\mathrm{n}^{\circ}$ 84.078-7/MG, o Ministro Marco Aurélio posicionou-se contrário à possibilidade da execução provisória da pena, por entender que não poderia haver um esvaziamento progressivo da presunção de inocência, eis que na medida, em que vão se sucedendo os graus de jurisdição, presunção só poderia sucumbir em face do preconizado no texto Constitucional com o trânsito em julgado da sentença penal condenatória.

Ao passo que o Ministro Luís Roberto Barroso, ao discorrer, nos autos do habeas corpus $n^{0} 126.292$, sobre a necessidade de ponderação e sua efetiva concretização, asseverou não existir dúvida de que o peso do princípio da presunção de inocência torna-se "gradativamente menor na medida em que o processo avança, em que as provas são produzidas e as condenações ocorrem”. Percebe-se que a contrariedade é manifesta entre os dois entendimentos num espaço de sete anos.

Ao se verificar que o princípio da presunção de inocência é a baliza mestra da aplicação do direito de punir do Estado, sob uma ótica estritamente constitucional e garantista, fica evidente que esse atual entendimento afrontou a literalidade do art. $5^{\circ}$, inciso LVII, da Constituição da República de 1988, pois, da leitura do aludido enunciado normativo, extrai-se, claramente e sem maiores elucubrações, que ninguém poderá ser considerado culpado até que haja o trânsito em julgado de édito penal condenatório.

Assim, ao tentar reescrever o postulado constitucional da presunção de inocência, a Corte Suprema se sub-rogou no papel do legislador constituinte, e mais, rompeu a integridade do sistema até então vigente, e sob a perspectiva “dworkiana” não foi coerente com as decisões anteriormente proferidas e já pacificadas. Além disso, sob a perspectiva do acusado presumidamente inocente seria difícil explicar com o voto do Ministro Luís Roberto Barroso: 
como uma pessoa acusada de um crime é menos ou mais inocente a medida que seu processo avance?

Em seu voto, o argumento, evidentemente ilustra a relativização de princípios fundamentais e indica um alto grau de seletividade em ponderar, pois ao analisar a questão da possibilidade de cumprimento da pena em segunda instância, ainda que pendente julgamento pelas instâncias especial e extraordinária, vislumbra-se que a medida que a pretensão acusatória vá avançando e tenha êxito, o princípio da presunção em relação ao acusado vá perdendo seu peso em relação a outros bens jurídicos fundamentais tutelados.

Por esse raciocínio da diminuição gradativa da inocência de alguém, é preciso verificar ainda que por uma questão de lógica e de coerência, o contraditório, ampla defesa e duplo grau de jurisdição por essa decisão, também não o são?

Poderia ser aventado que em 2009, ao julgar o habeas corpus $n^{\circ}$ 84.078-7/MG, teria o Supremo Tribunal Federal também provocado um desencadeamento do romance que vinha sendo escrito, ao mudar o entendimento que se encontrava sedimentado na Corte até então, no sentido de ser admissível a execução provisória da pena, ainda que pendentes de julgamento recurso especial ou extraordinário.

Há que se observarem dois fundamentos: primeiro, o dogmático, no sentido de que conforme já dito, embora houvesse a possibilidade do réu poder cumprir provisoriamente a pena, não se ponderava a questão da relativização da presunção de inocência. A Corte Suprema sempre vislumbrou naquela decisão permissiva da execução provisória, antes de tudo, um benefício ao réu que poderia mesmo que preso provisoriamente, cumprir a pena antes do trânsito em julgado, para progredir de regime.

E segundo que, teoricamente, em relação a teoria de Ronald Dworkin naquela ocasião não houve uma ruptura, mas uma adequação dos rumos do romance em cadeia, pois o capítulo precedente escrito pelo romancista, o constituinte, já era o enredo que vinha sendo desenvolvido em inúmeros julgados do Supremo Tribunal Federal e não se mostrava adequada a ideia original do romance, prevista no inciso LVII do art. $5^{\circ}$ da Constituição da República, tal como observado pelo Ministro Eros Graus, relator do habeas corpus nº 84.078-7/MG.

Registre-se que adequar à ideia principal, permitindo que o enredo fique a ela subordinado, é muito diferente de iniciar- se uma nova história. Ademais, o Brasil é um Estado Democrático de Direito e como tal somente se legitima quando reconhece direitos às pessoas, 


\section{RELATIVIZAÇÃO DA PRESUNÇÃO DE INOCÊNCIA SOBRE O PRISMA DA \\ INTEGRIDADE E COERÊNCIA DE RONALD DWORKIN}

dentre os quais o direito a de ser reconhecido como inocente até que sobrevenha o trânsito em julgado da sentença penal condenatória (DEZEN, 2008, p. 36).

\section{DA (IN) COERÊNCIA DOS RECURSOS ESPECIAL E EXTRAORDINÁRIO}

\section{NA SEARA PENAL E A (IN) CONSTITUCIONALIDADE DO ARTIGO 283 DO CÓDIGO DE PROCESSO PENAL}

O argumento que também é invocado na relativização do princípio da presunção de inocência é o de que a ausência de efeito suspensivo dos recursos especial e extraordinário justificaria a tese da execução antecipada da pena.

Trata-se de mais uma visão equivocada da Teoria Geral do Processo que volta para atormentar o já fragilizado processo penal brasileiro. $\mathrm{O}$ revogado $\S 2^{\circ}$ do art. 27 da Lei $\mathrm{n}^{\circ}$ 8.038/1990, assim como o caput do art. 995 do novo Código de Processo Civil, não pode ser aplicado ao processo penal, por desconsiderar suas categorias jurídicas próprias, estruturas completamente diferentes e ainda, não manter a coerência com o sistema punitivo.

É importante sempre frisar que o problema de se prender antes do trânsito em julgado e sem caráter cautelar, não se reduz ao mero problema de “efeito recursal”. É da liberdade de alguém que se está tratando e, portanto, da esfera de compreensão dos direitos e liberdades individuais, tutelados - entre outros princípios - pela presunção de inocência.

É preciso retomar ainda, o que disse o então Ministro Eros Grau no acórdão do Habeas Corpus $\mathrm{n}^{0}$ 94.408, julgado no dia 10 de fevereiro de 2009, também, oportunidade em que afirmou categoricamente a "inconstitucionalidade da chamada execução antecipada da pena".

“O art. 637 do CPP estabelece que o recurso extraordinário não tem efeito suspensivo, e uma vez arrazoado pelo recorrido os autos do traslado, os originais baixarão à primeira instância para a execução da sentença. A Lei de Execução Penal condicionou a execução da pena privativa de liberdade ao trânsito em julgado da sentença condenatória. A Constituição do Brasil de 1988 definiu, em seu art. 5º, inciso LVII, que "ninguém será considerado culpado até o trânsito em julgado de sentença penal condenatória”. Daí que os preceitos veiculados pela Lei n. 7.210/84, além de adequados à ordem constitucional vigente, 
sobrepõem-se, temporal e materialmente, ao disposto no art. 637 do CPP. A prisão antes do trânsito em julgado da condenação somente pode ser decretada a título cautelar. A ampla defesa, não se a pode visualizar de modo restrito. Engloba todas as fases processuais, inclusive as recursais de natureza extraordinária. Por isso a execução da sentença após o julgamento do recurso de apelação significa, também, restrição do direito de defesa, caracterizando desequilíbrio entre a pretensão estatal de aplicar a pena e o direito, do acusado, de elidir essa pretensão. Prisão temporária, restrição dos efeitos da interposição de recursos em matéria penal e punição exemplar, sem qualquer contemplação, nos “crimes hediondos” exprimem muito bem o sentimento que Evandro Lins sintetizou na seguinte assertiva: “Na realidade, quem está desejando punir demais, no fundo, no fundo, está querendo fazer o mal, se equipara um pouco ao próprio delinquente. A antecipação da execução penal, ademais de incompatível com o texto da Constituição, apenas poderia ser justificada em nome da conveniência dos magistrados - não do processo penal. A prestigiar-se o princípio constitucional, dizem, os tribunais (leia-se STJ e STF) serão inundados por recursos especiais e extraordinários e subsequentes agravos e embargos, além do que "ninguém mais será preso”. Eis o que poderia ser apontado como incitação à “jurisprudência defensiva”, que, no extremo, reduz a amplitude ou mesmo amputa garantias constitucionais. "A comodidade, a melhor operacionalidade de funcionamento do STF não pode ser lograda a esse preço.”

Carnelutti, dizia que há uma diferença insuperável entre o processo civil e o processo penal, qual seja: enquanto o processo civil se ocupa do "ter”, o processo penal lida como o “ser”. (CARNELUTTI, 2009, p. 28). Portanto, é de outra situação - que não mero efeito recursal - que estamos tratando ao discutir a eficácia temporal da garantia constitucional da presunção de inocência. E, para finalizar, uma vez mais é preciso recordar que a Constituição expressamente estabelece a proibição de se tratar como culpado - e, portanto, há uma inconstitucional equiparação ao mandá-lo para a “mesma” prisão - aquele que ainda é simples acusado, antes do trânsito em julgado. 


\section{RELATIVIZAÇÃO DA PRESUNÇÃO DE INOCÊNCIA SOBRE O PRISMA DA INTEGRIDADE E COERÊNCIA DE RONALD DWORKIN}

Enfim, o conceito de trânsito em julgado não tem absolutamente nenhuma relação com o efeito recursal e, portanto, qualquer aplicação nesse sentido estaria fora do âmbito da coerência e integridade do sistema constitucional vigente em nosso país.

Há que se observar que, do ponto de vista lógico, a conclusão de que a presunção de inocência só teria aplicação até o julgamento em segundo grau de jurisdição e, consequentemente, depois do julgamento do mérito pelo tribunal local, mesmo que houvesse a interposição de recurso especial ou extraordinário, seria possível a expedição de mandado de prisão, com o início de execução provisória da penal, deveria implicar consequentemente no reconhecimento da inconstitucionalidade do art. 283 do Código de Processo Penal.

O art. 283 do Código de Processo Penal, com a redação dada apela Lei $n^{\circ}$ 12.403, assegura:

“Art. 283. Ninguém poderá ser preso senão em flagrante delito ou por ordem escrita e fundamentada da autoridade judiciária competente, em decorrência de sentença condenatória transitada em julgado ou, no curso da investigação ou do processo, em virtude de prisão temporária ou prisão preventiva”.

Na presente decisão não há qualquer menção ao art. 283 e tampouco uma declaração fundamentada de sua inconstitucionalidade, pois ele é completamente incompatível com a decisão proferida pelo STF. Como simplesmente diante de inúmeros casos ‘não aplicar’ o art. 283 sem declarar previamente sua inconstitucionalidade? A problemática foi tratada por Streck, ${ }^{5}$ quando analisando a decisão proferida pelo Min. Teori Zavascki, ainda no Superior Tribunal de Justiça, no voto na Recl. 2.645, quando diz: não se admite que seja negada aplicação, pura e simplesmente, a preceito normativo "sem antes declarar formalmente a sua inconstitucionalidade”.

Ou seja, não se pode deixar de aplicar um texto normativo sem lhe declarar, formalmente a inconstitucionalidade. Consequentemente, segue questionando Streck, se esse

\footnotetext{
${ }^{5}$ Lenio Streck - Opinião: Teori do STF contraria Teori do STJ ao ignorar lei sem declarar inconstitucional, disponível em: [http://www.conjur.com.br/2016-fev-19/streck-teori-contraria-teoriprender-transito-julgado]. Acesso em 20.05.2016
} 
dispositivo não foi declarado inconstitucional, então houve o quê? "Interpretação do instituto da prisão provisória à luz da CF”? Mais esse novo entendimento não deu azo a uma súmula vinculante e nem poderia, mesmo que tivesse oito votos, porque a CF é clara, em seus limites semânticos, no sentido de que são necessárias reiteradas decisões.

Portanto, na medida em que não é cabível a tese da abstração ou objetivação do controle difuso porque, no caso, nem declaração de inconstitucionalidade houve, não caberá reclamação da decisão de um tribunal que resolva não aplicar a nova posição do STF. Portanto, se chega a seguinte conclusão: de duas uma, ou o acórdão violou direta e frontalmente o disposto no caput do art. 283 do Código de Processo Penal, e isso precisa ser reformado e suprindo-se tal omissão do v. acórdão; ou o referido dispositivo é inconstitucional e assim precisa ser expressamente declarado.

O que não pode ocorrer é simplesmente não enfrentar a (in) constitucionalidade do referido dispositivo, sobre tema de tamanha relevância prática, com imenso prejuízo para a liberdade dos acusados.

\section{DOS INSTITUTOS DA LEI DE EXECUÇÃO PROVISÓRIA.}

Além dos regramentos normativos previsto do enunciado no art. 283 do Código de Processo Penal (CPP), pelo qual se condiciona a imposição de prisão-pena ao trânsito e julgado de sentença penal condenatória, a Lei de Execuções Penais, também contemplou a presunção de inocência ao erigir como conditio sine qua non à execução penal, quer se cuide de imposição de pena corporal ou restritiva de direitos diferentes da liberdade, a formação da coisa julgada material oriunda de sentença penal condenatória.

Atente-se, pois, ao que se estabelece nos artigos 105 e 147 do referido documento normativo, verbis: “Art. 105. Transitando em julgado a sentença que aplicar pena privativa de liberdade, se o réu estiver ou vier a ser preso, o Juiz ordenará a expedição de guia de recolhimento para a execução”; e “Art. 147. Transitada em julgado a sentença que aplicou a pena restritiva de direitos, o Juiz da execução, de ofício ou a requerimento do Ministério Público, promoverá a execução, podendo, para tanto, requisitar, quando necessário, a colaboração de entidades públicas ou solicitá-la a particulares”. 


\section{RELATIVIZAÇÃO DA PRESUNÇÃO DE INOCÊNCIA SOBRE O PRISMA DA INTEGRIDADE E COERÊNCIA DE RONALD DWORKIN}

Assim, mostra-se conteste a positivação explícita da presunção de inocência no sistema normativo brasileiro. Não significa dizer, todavia, que inexiste controvérsia quanto à atividade interpretativa que se lhe busca imprimir nos ambientes doutrinário e jurisprudencial, sobretudo no que concerne a seus limites e diálogos normativos.

A persecução penal revela-se num caminho procedimental-processual que se compõe, em regra, de três fases, a saber: a investigativa, com o inquérito policial ou outro procedimento equivalente; a cognitiva (processo de conhecimento), em que o titular da ação penal deduz a um órgão jurisdicional competente sua pretensão condenatória; e, sendo essa pretensão acolhida e ocorrida a preclusão máxima, abre-se a última fase, a executória (processo de execução), na qual se visa a impor ao réu as sanções decretadas na fase anterior.

À evidência, o que se está a destacar é a terceira fase da execução penal, conceituada por Guilherme Souza Nucci (2016, p. 781) como a “fase do processo penal, em que se faz valer o comando contido na sentença condenatória penal, impondo-se, efetivamente, a pena privativa de liberdade, a pena restritiva de direitos ou a pecuniária”.

Visto isso, pode-se verificar claramente que a execução penal antecipada (ou provisória), qual seja: a imposição ao réu, a título definitivo, em momento processual anterior ao trânsito em julgado da decisão judicial condenatória (sentença ou acórdão), das sanções penais aplicadas por essa, independentemente da análise dos fundamentos e requisitos para a segregação cautelar só poderá ser realizada para possibilitar ao réu a progressão de regime prisional e em seu favor.

O ponto principal diz respeito à execução penal provisória contrária aos interesses do réu (contra reo), os quais, numa palavra, correspondem à preservação de sua liberdade, por isso, fácil deduzir, que tal acepção se contrapõe à antecipação da execução penal que lhe favorece (execução penal provisória pro reo).

Essa distinção mostra-se pertinente haja vista não ser incomum no processo penal brasileiro que o acusado possa gozar, durante o período em que cumpre prisão processual (sobretudo a prisão preventiva), de benefícios próprios da fase processual executória, a exemplo da progressão de regime prisional e da aplicação imediata de regime menos gravoso, conforme autorizam os enunciados n. 716 e 717 da súmula da jurisprudência dominante do Supremo Tribunal Federal. Ainda, a própria Lei de Execução Penal, no parágrafo único de seu art. $2^{\circ}$, permite que suas regras sejam aplicadas ao preso provisório. 
Almeja-se com isso demonstrar que, diferentemente da relação entre execução penal provisória contra reo e presunção de inocência - a harmonia entre a execução penal antecipada em favor do réu e a referida garantia é constatada por um simples esforço interpretativo, qual seja a compreensão de que garantias constitucionais não podem ser utilizadas contra seus destinatários.

É como se manifesta Dezem (2017, p. 321), ao dissertar que em tais casos aplica-se “a ideia de que direito fundamental não pode ser utilizado contra seu titular. Daí porque, estando o acusado preso, não pode ser utilizada a presunção de inocência contra o titular do direito”.

Nesse mesmo tom, Nucci (2016, p. 678) defende a consonância entre execução penal provisória em favor do réu e a presunção de inocência, pois os “direitos e garantias fundamentais [...] servem para a proteção do indivíduo, e não para prejudicá-lo, o que aconteceria caso fosse utilizado como causa impeditiva da execução provisória”.

Expôs-se que, diferentemente das prisões processuais, a imposição da prisão penal fazse mediante cognição exauriente. Daí que se condiciona a prisão-pena, nos termos dos artigos 5 , LVII, da Constituição Federal, 283, do Código de Processo Penal e 105, da Lei de Execução Penal à formação da coisa julgada material..

A coisa julgada encontra-se definida no art. $6^{\circ}, \S 3^{\circ}$, da Lei de Introdução às Normas do Direito Brasileiro e, com mais tecnicidade jurídico-processual , no art. 502, caput, da Lei n. 13.015, de 2015 (Código de Processo Civil), a prever que se denomina “coisa julgada material a autoridade que torna imutável e indiscutível a decisão de mérito não mais sujeita a recurso”.

Nesse prisma, Aury Lopes Jr. (2016, p. 742), com base nas lições de Enrico Tullio Liebman, explica que:

\footnotetext{
"a coisa julgada não é o efeito ou um efeito da sentença, mas uma qualidade e um modo de ser e de manifestar-se de seus efeitos. É algo que se agrega a tais efeitos para qualificá-los e reforçá-los em um sentido bem determinado. Não há que se confundir uma qualidade dos efeitos da sentença com um efeito autônomo dela, e nisto consiste a autoridade da coisa julgada, que se pode precisamente definir como a imutabilidade do mandamento proveniente da sentença. Não se identifica com a definitividade ou intangibilidade do ato que pronuncia o mandamento; é, em câmbio, uma qualidade especial, mais intensa e mais profunda, que afeta o ato e inclusive seu conteúdo, e o torna, desse modo, imutável, não só no seu aspecto formal, mas também dos efeitos desse mesmo ato".
}

Assim, sem olvidar as características e peculiaridades que diferenciam a coisa julgada penal da coisa julgada cível, sobretudo em virtude da vocação garantista da primeira, percebe- 


\section{RELATIVIZAÇÃO DA PRESUNÇÃO DE INOCÊNCIA SOBRE O PRISMA DA INTEGRIDADE E COERÊNCIA DE RONALD DWORKIN}

se que a legislação ordinária em nenhum momento deixa evidente a possibilidade de execução provisória no sentido de relativização da presunção de inocência.

\section{CONSIDERAÇÕES FINAIS}

Nas democracias, os principais, os limites ao poder são os direitos e garantias fundamentais. Cada vez que um limite é afastado, cada vez que um direito ou uma garantia fundamental é relativizado, o Estado caminha em direção ao autoritarismo. Os motivos expostos pelos defensores da relativização da presunção de inocência não são novos, independente do Poder que emanam. Aliás, em todo momento autoritário, essa linha argumentativa se faz presente. Basta lembrar, dos argumentos contrários à presunção de inocência presentes na obra de Vincenzo Manzini, marco legislativo do fascismo clássico italiano. (MANZINI, 2010, p. 1931)

No fascismo clássico Italiano e no sistema de justiça penal nazista, a presunção de inocência de alguma forma foi excluída ou relativizada. Aliás, a expressão "presunção de não culpabilidade”, utilizada ainda hoje por parcela da doutrina brasileira, surgiu e foi defendida por teóricos ligados por esse mesmo fascismo italiano, como forma de enfraquecer no plano linguístico a garantia do estado de inocência. Note-se que, ao contrário do que pretendem alguns dos defensores da relativização da presunção de inocência, não é possível ponderar, de um lado, o interesse abstrato à segurança pública ou o interesse de coletividade, e, de outro, o interesse concreto relativo à liberdade de um indivíduo, isso porque, como demonstrou Ronald Dworkin, não é legítimo o sopesamento de interesses de densidade distinta, sob pena, de se tornar possível à violação de qualquer interesse individual mediante a desculpa retórica de se estar protegendo o interesse público, a segurança de todos ou mesmo combatendo a corrupção.

Aliás, essa ponderação entre interesses de densidades distintas era normal na Alemanha nazista, onde os discursos de proteção dos valores do povo alemão ou “combate à corrupção” foram utilizados para aniquilar os direitos individuais de parcela da população ${ }^{6}$. No Brasil, a importância da Constituição, dos limites impostos pelos direitos fundamentais e do

\footnotetext{
${ }^{6}$ Gellately, Robert. Apoiando Hitler: consentimento e coerÇão na Alemanha nazista. ED. Record, 2012.
} 
caráter contra majoritário do Poder Judiciário não integra a compreensão do cidadão. A falta de uma cultura, materialmente democrática, faz com que os direitos fundamentais sejam percebidos como obstáculos à eficiência repressiva do Estado.

Realizadas essas considerações, é possível concluir que as decisões proferidas nos autos dos habeas corpus n. ${ }^{\circ}$ 84.078-7/MG e 126.292/SP não passam pelo crivo interpretativo do romance em cadeia proposto por Ronald Dworkin, uma vez que, neste último julgado o Supremo Tribunal Federal, deu início a uma nova história, sem qualquer correspondência ou correlação com o entendimento anterior adotado, e, mais do que isso, sem qualquer correspondência, também com o capítulo inaugural do romance, qual seja, o art. $5^{\circ}$, inciso LVII da Constituição da República.

Impossível admitir-se à luz da atual ordem constitucional brasileira, a viabilidade da execução provisória da pena, vale dizer, o início do cumprimento da pena antes que sobrevenha o trânsito em julgado da sentença penal condenatória, execução esta que, justamente por ser provisória, mostra-se incompatível com a exigência constitucional da imutabilidade do julgado condenatório para que a presunção de inocência deixe de existir.

O Supremo Tribunal Federal, no julgamento do habeas corpus $n^{\circ} 126.292 / S P$ promoveu um desencadeamento total do romance iniciado em 1988, com o constituinte originário, eis que a decisão tomada em 2009 estava no rumo certo do romance original na Carta da República.

Sendo assim, decidiu-se de maneira contrária ao princípio da presunção de inocência e referida decisão não tem o menor grau de coerência ou integridade dentro do nosso sistema. Houve um retrocesso injustificável numa garantia constitucional prevista que não contém relativização, ou seja, o Pretório Excelso interpretou de forma política a questão, gerando uma enorme insegurança jurídica. Por ora, fácil concluir que a decisão tomada em relação ao princípio da presunção de inocência foi nitidamente casuística e causa grande preocupação a postura da Suprema Corte em relativizar garantias tão caras da nossa constituição, que vem se tornando comum atualmente.

No Brasil, os princípios fundamentais na ordem constitucional ultimamente são vistos sob a ótica política e podem ser suprimidos na calada da noite. Não há respeito à integridade do sistema, não há respeito aos fundamentos da República Federativa do Brasil, pois a estrutura lógica dos julgamentos realizados pela Suprema Corte, leva em conta o momento político vigente. Analisando as hipóteses apresentadas chega-se a conclusão de que não há no direito brasileiro uma espinha dorsal ou um norte seguro, coerente e íntegro a ser seguido, eis que a 


\section{RELATIVIZAÇÃO DA PRESUNÇÃO DE INOCÊNCIA SOBRE O PRISMA DA INTEGRIDADE E COERÊNCIA DE RONALD DWORKIN}

própria Constituição não tem servido de parâmetro para as questões essenciais garantidoras de toda a sociedade.

Ainda que alguns entendam que esse nova orientação do STF, guardião da nossa Constituição constitua um avanço no combate à impunidade e sirva como instrumento para a redução da criminalidade, percebe-se que a modificação do paradigma até então prevalente, constitui um verdadeiro ataque à garantia fundamental da presunção de inocência, sendo, assim, um retrocesso lamentável no sistema jurídico brasileiro. De fato, o texto constitucional é claro no sentido de que a sentença condenatória só pode ser executada depois do seu trânsito em

julgado, ou seja, quando não exista mais possibilidade de recurso. Assim, se há recurso pendente de julgamento, independente da análise das questões de fato ou de direito, a decisão, ainda que confirmada em segunda instância, não transitou em julgado e, portanto, não há possibilidade de punição do autor de um fato criminoso, que ainda deve ser presumido inocente.

A referida mudança de entendimento se trata de verdadeiro "malabarismo hermenêutico" do Supremo Tribunal Federal que, lamentavelmente, parece ter deixado de lado a defesa da Constituição Federal da República de 1988 e do Estado Democrático de Direito para atender os conclames das ruas, proferindo decisões com nítido fundamento político e casuístico. Claramente trata-se de um retumbante erro histórico do Supremo Tribunal Federal cujos impactos poderão ser severos como o aumento da população carcerária que fatalmente será um deles.

\section{REFERÊNCIAS BIBLIOGRÁFICAS}

ALEXY, Robert. Constitucionalismo discursivo. 3. ed. Porto Alegre: Livraria do Advogado, 2011.

. Teoria de los derechos fundamentales. Trad.: Virgílio Afonso da Silva. 5. ed. São Paulo: Malheiros, 2012.

BARROSO, Luis Roberto. Curso de direito constitucional contemporâneo: os conceitos fundamentais e a construção do novo modelo. São Paulo: Saraiva, 2009

BECCARIA, Cesare. Dos delitos e das penas. 18. ed. Rio de Janeiro:Lumen Juris,2010.

BRASIL. Supremo Tribunal Federal Pleno. Habeas Corpus 84.078-7/MG

BRASIL. Supremo Tribunal Federal Pleno. Habeas Corpus 126.292/SP 
CARNELUTTI, Francesco. As misérias do processo penal. Trad.: versão espanhola do original italiano por Carlos Eduardo Trevelin Millan. São Paulo: ed. Pillares, 2009.

DEZEN, Guilherme Madeira. Presunção de inocência: efeito suspensivo dos recursos extraordinário e especial e execução provisória. Revista Brasileira de Ciências Criminais. Vol. 70/208. Jan-Fev/2008, p. 269-290.

DWORKIN, Ronald. O império do direito. Trad:.Jefferson Luiz Camargo. 2a . ed. São Paulo: Martins Fontes.2007.

DWORKIN, Ronald. O direito de liberdade - a leitura moral da Constituição norte americana - ed. Martins Fontes. São Paulo. 2006

DWORKIN, Ronald. Levando os direitos a sério. Trad. Nelson Boeira. 3. Ed. São Paulo: Martins Fontes, 2010.

DWORKIN, Ronald. Uma questão de princípio. Trad:.Luiz Carlos Borges. 2a . ed. São Paulo: Martins Fontes.2005.

GELLATELY, ROBERT. APOIANDO HITLER: CONSENTIMENTO E COERÇÃO NA ALEMANHA NAZISTA. ED. RECORD, 2012.

LOPES JR, Aury. Direito Processual Penal. 13a . ed. São Paulo: Saraiva, 2016

MENDES, Gilmar Ferreira. Curso de direito Constitucional. 7. ed.rev. São Paulo: Saraiva, 2012.

MORAIS, DA Rosa, Alexandre. A Teoria dos Jogos aplicada ao processo penal. 2. ed. Empório do Direito, 2016.

STRECK, Lenio Luiz. Hermenêutica jurídica em crise. 2.ed. Porto Alegre: Livraria do Advogado, 2000.

- Verdade e Consenso: constituição e teorias discursivas: da possibilidade à necessidade de respostas corretas em direito. 3.ed.rev e ampl. Rio de janeiro: lumen Juris, 2009. 